\title{
Conclusions from the Mexican National Nutrition Survey 1999: translating results into nutrition policy
}

Juan A Rivera, MS, PhD, (1) Jaime Sepúlveda A mor, MD, ScD. ${ }^{(2)}$

\begin{abstract}
Rivera JA, Sepúlveda-Amor J. Conclusions from the Mexican National Nutrition Survey 1999:Traslating results into nutrition policy. Salud Publica Mex 2003;45 suppl 4:S565-S575. The English version of this paper is available too at: http://www.insp.mx/salud/index.html
\end{abstract}

\begin{abstract}
Objective This article presents and overview of the main results and conclusions from the Mexican $\mathrm{N}$ ational N utrition Survey 1999 (N N S-1999) and the principal nutrition policy implications of the findings. Material and Methods The N N S-1999 was conducted on a national probabilistic sample of almost 18000 households, representative of the national, regio nal, as well as urban and rural levels in Mexico. Subjects included were children $<12$ years and women 12-49 years. Anthropometry, blood specimens, diet and socioeconomic information of the family were collected. Results. The principal public nutrition problems are stunting in children < 5 years of age; anemia, iron and zinc deficiency, and low serum vitamin C concentrations at all ages; and vitamin A deficiency in children. Undernutrition (stunting and micronutrient deficiencies) was generally more prevalent in the lower socioeconomic groups, in rural areas, in the south and in Indigenous population. 0 verweight and obesity are serious public health problems in women and are already a concern in school-age children. Conclusions A number of programs aimed at preventing undernutrition are currently in progress; several of them were designed or modified as a result of the N N S-1999 findings. Most of them have an evaluation component that will inform adjustments or modifications of their design and implementation. However, little is being done for the prevention and control of overweight and obesity and there is limited experience on effective interventions. The design and evaluation of prevention strategies for controlling obesity in the population, based on existing evidence, is ur-
\end{abstract}

\author{
Rivera JA, Sepúlveda-Amor J. \\ Conclusiones de la Encuesta Naciona \\ de Nutrición 1999: traduciendo resultados \\ a política nutricional. \\ Salud Publica Mex 2003;45 supl 4:S565-S575. \\ El texto completo en inglés de este artículo también \\ está disponible en: http://www.insp.mx/salud/index.html
}

\section{Resumen}

Objetivo. Este artículo presenta una visión general de los resultados y conclusiones más importantes de la Encuesta $\mathrm{N}$ acional de N utrición realizada en México en 1999 (EN N 1999) y sus principales implicaciones para políticas públicas sobre nutrición. Material y métodos. La EN N-1999 fue realizada en una muestra probabilística de cerca de 18000 hogares, representativa de los ámbitos nacional, regional y de zonas urbanas y rurales en México. Se incluyó a niños menores de 12 años y mujeres de 12 a 49 años. Se obtuvieron mediciones antropométricas, muestras de sangre, dieta e información socioeconómica de los ho gares. Resultados. Los principales problemas de nutrición pública en México son baja talla en menores de 5 años; anemia, deficiencia de hierro y zinc y concentraciones séricas bajas de vitamina $\mathrm{C}$ en todas las edades; $y$ deficiencia de vitamina $A$ en niños. La desnutrición (baja talla y deficiencia de micronutrimentos) fue más prevalente en los grupos con bajo nivel socioeconómico, en zonas rurales, el sur y en población indígena. El sobrepeso y la obesidad son serios problemas de salud pública en mujeres y ya constituyen motivo de preocupación en niños de edad escolar. Conclusiones Un importante número de programas dirigidos a prevenir la desnutrición se aplican actualmente; varios de ellos fueron diseñados 0 modificados como resultado de los hallazgos de la EN N 1999. La mayor parte de ellos tienen un componente de evaluación que guiará ajustes y modificaciones de su diseño e implementación. Sin embargo poco se está haciendo para la prevención y control de sobrepeso y obesidad y hay ex-

(1) Centro de Investigación en N utrición y Salud, Instituto N acional de Salud Pública (IN SP), Cuernavaca, Morelos, México.

(2) Dirección General del IN SP, Cuernavaca, Morelos, México.

Received on: 0 ctober 23,2003 •Accepted on: 0 ctober 23, 2003

Address reprint requests to: Juan A Rivera. Centro de Investigación en Nutrición y Salud, Instituto N acional de Salud Pública. A venida Universidad No 655, colonia Santa María A huacatitlan, 62508 Cuernavaca Morelos, México.

E-mail: jrivera@ insp.mx 
gently needed and success stories should be brought to scale quickly to maximize impact. The English version of this paper is available too at: http://www.insp.mx/salud/index.html

Key words: nutritio nal status; stunting; anemia; micronutrient deficiencies; overweight; obesity; Mexico periencia limitada sobre inter venciones efectivas. Se necesita urgentemente el diseño y evaluación de estrategias para controlar la obesidad en la población, con base en evidencia existente y las acciones exitosas deben convertirse en programas de gran escala rápidamente con el propósito de maximizar su impacto. El texto completo en inglés de este artículo también está disponible en: http://ww w.insp.mx/salud/index.html

Palabras clave: estado de nutrición; baja talla; anemia; deficiencia de micronutrimentos; so brepeso; obesidad; México,
$\mathrm{N}$ utrition throughout the life cycle is one of the main determinants of health, as well as physical and mental performance. Undernutrition during early life increases the risk of disease and mortality and impairs growth and development during early childhood. Its negative impact spills into adolescence and adulthood, reducing work capacity and intellectual performance, ${ }^{1}$ which may in turn decrease economic productivity. Undernutrition during other periods of life can also have adverse consequences on health and performance. For example, anemia and micronutrient deficiencies in school age children can affect health and school attendance, performance and learning, ${ }^{2}$ with negative consequences in human capital development. Overnutrition, another form of malnutrition, is a well known risk factor for various non-communicable chronic diseases ${ }^{3}$ which increase the risk of premature death, and impose an economic burden on health services. ${ }^{4}$

Malnutrition (both undernutrition and overnutrition) have complex causes that involve biological as well as socioeconomic and cultural determinants. Child undernutrition results from poor diets, in quantity and/ or quality, and from infectious diseases; these factors are rooted in insufficient access to nutritious foods, poor sanitation and health services, and inadequate parental care practices. ${ }^{5}$ The roots of these issues lie in the uneven distribution of resources, knowledge and opportunities among the members of the society where undernutrition is most prevalent.

Overnutrition and obesity result from the imbalance between energy intake and expenditure. This imbalance is most often the consequence of the intake of energydense and low fiber diets in combination with reduced physical activity. The latter has been linked to urbanization, economic growth, and changes in technology for work, as well as changes in lifestyles and leisure. ${ }^{6}$

The prevention of malnutrition is of paramount importance, given its significance for the health and performance of the population. The multi-factorial causation of malnutrition calls for multi-sector policies and programs to prevent or ameliorate the problem and its consequences.

Reliable and timely information about the nutritional status of the population and its key determinants is required periodically for planning policies and programs. The first nutrition probabilistic survey in a national sample in Mexico was conducted in 1988 by the Secretary of Health. The National Institute of Public Health thought it to be important to update the information on the nutritional situation in Mexico and conducted, between 1998 and 1999, the second National Nutrition Survey, referred to thereafter as the National Nutrition Survey 1999 (NNS-1999).

This article provides a brief overview of the papers included in this volume, complemented with results from other publications of findings of the NNS-1999 and some original unpublished results. It also addresses some of the main policy implications of the findings and how the results of the survey have influenced nutrition policy.

\section{Material and Methods}

Sample and design. The NNS-1999 was conducted by the National Institute of Public Health of Mexico between October 1998 and March 1999 in a national probabilistic sample of 17944 households in Mexico. The sampling methodology as well as the response rates are described in detail in an article published in this same issue. ${ }^{7}$ The resulting sample is representative of the national level, of urban ( $\geq 2500$ people) and rural ( $<2500$ people) sites and of four geographic regions which include the following states: north (Baja California, Baja California Sur, Coahuila, Chihuahua, Durango, Nuevo León, Sonora, and Tamaulipas), center (Aguascalientes, Colima, Guanajuato, Jalisco, México (excluding the municipalities that are part of the Mexico City), Michoacán, Morelos, Nayarit, Querétaro, San Luis Potosí, Sinaloa, and Za- 
catecas), Mexico City (including the Federal District and the municipalities that are part of the metropolitan area) and south (Campeche, Chiapas, Guerrero, Hidalgo, Oaxaca, Puebla, Quintana Roo, Tabasco, Tlaxcala, Veracruz, and Yucatán).

Information was available on a total of 5471 households in the north, 5212 in the center, 1930 in Mexico City, and 5331 in the south.

The study population consisted of the following age groups: children $<5$ years of age $(n=8011)$, school-age children between 5 and 11 years $(n=11415)$, and women aged 12-49 years $(n=18311)$. The sample represented about 10.6 million children $<5$ years of age, about 15.6 million children 5-11 years and about 28.8 million women 12-49 years of age.

Questionnaires were applied, measurements obtained and biological samples collected for the total sample or in sub-samples. A brief account of the data collection relevant to this article follows. In the total sample, a questionnaire on household characteristics was applied alongside another on morbidity of children and women. On the same visit anthropometry (weight and height or length) was measured and capillary blood samples for hemoglobin determination obtained in all children and women 12-49 years of age. A questionnaire about breastfeeding and complementary feeding of children $<2$ years of age was applied in all households with children in this age range. A 24-hours dietary intake questionnaire was applied in one out of five households in the diet sub-sample that included all children in the household and one randomly selected woman. Venous blood and urine specimens were collected from a sub-sample of the diet sub-sample - referred to as the biochemical determinants sample - to determine the micronutrient concentrations and table salt was collected for determination of iodine concentration, as an indicator of effectiveness of salt fortification with iodine.

Consent was obtained from the mother or selfidentified decision maker in each household. The project was approved by the Human Subjects and Ethics Committee of the National Institute of Public Health.

Detailed descriptions of the methods employed for data collection of all measurements and for laboratory procedures are published elsewhere ${ }^{8}$ and are also described in details in other parts of this volume. The following is a list of each study area, followed by the citation of the article or articles in this issue where methods are described.

Anthropometric measurements in children less than 5 years ${ }^{9}$ and in children $5-11$ years, ${ }^{10}$ dietary intake of children ${ }^{11}$ and women, ${ }^{12}$ hemoglobin determination and definitions of anemia in children ${ }^{13}$ and women, ${ }^{14}$ meth- ods for the assessment of micronutrient status, ${ }^{15,16}$ breastfeeding ${ }^{17}$ and socioeconomic status classification. ${ }^{9}$

The principal variables included in this article are listed and defined below:

Length/height and weight data in children $<5$ years were transformed to z-scores using the WHO/ NCHS/CDC reference data. ${ }^{18}$ Children were classified as underweight, stunted and wasted when their $\mathrm{z}$ scores were $<-2$ for weight-for-age, length/height-forage and weight-for-length/height, respectively. Children $<5$ years were classified as overweight when their z-score $>+2$ for weight for length. Classification of overweight and obesity in children 5-11 years and non-pregnant women used the Body Mass Index (BMI $=$ weight $\{\mathrm{kg}\} /$ height $\left.^{2}\left\{\mathrm{~m}^{2}\right\}\right)$. For school age children the age and sex specific cutoff points, as suggested by the International Obesity Task Force ${ }^{19}$ were employed. These cutoff points are based on a reference population which includes data from different countries and generates age specific BMI cutoff points for children linked to the adult BMI cutoff points of $25 \mathrm{~kg} / \mathrm{m}^{2}$ (overweight) and $30 \mathrm{~kg} / \mathrm{m}^{2}$ (obesity). These two cutoffs for the classification of overweight and obesity for adults were used for the classification of women as overweight or obese in this article. ${ }^{20}$

Anemia was defined as a concentration of hemoglobin at sea level of $<11.0 \mathrm{~g} / \mathrm{dl}$ in children $1-5$ years old and pregnant women, $9.5 \mathrm{~g} / \mathrm{dl}$ in children 6-11 months of age and $<12.0 \mathrm{~g} / \mathrm{dl}$ in children 6-11 years and non-pregnant women. ${ }^{21,22}$ The values for each location were adjusted according to their altitude above sea level. ${ }^{23,24}$ Altitude data were obtained from INEGI (the Mexican Institute of Information, Geography and Statistics). ${ }^{25}$

Micronutrient deficiencies were defined as follows. Iron deficiency as Percent Transferrin Saturation $<16,{ }^{26}$ zinc deficiency as serum zinc concentrations $<65 \mathrm{ug} /$ $\mathrm{dl}$, as recommended by the International Zinc Nutrition Consultative Group (IZiNCG), vitamin A deficiency as serum retinol $<20 \mu \mathrm{g} / \mathrm{dl}$, folate deficiency as folate concentrations in erythrocytes $<140 \mathrm{ng} / \mathrm{ml},{ }^{27}$ and vitamin $\mathrm{C}$ deficiency as ascorbic acid serum concentrations $<0.2 \mathrm{mg} / \mathrm{dl}^{28}$

Exclusive breast-feeding was defined as consuming nothing but breast milk. Having ever breast-fed was defined as having ever suckled at the breast to receive colostrum or breast milk. Median duration of any breastfeeding was estimated through moving averages.

Nutrient adequacies were estimated using as reference the Estimated Average Requirements (EARs) from the Dietary Reference Intakes (DRIs) when available (Iron, zinc, vitamin A and C, and folate $)^{29}$ and the Recommended Dietary Allowances (RDAs) for energy. ${ }^{30}$ 
Several analyses are presented by geographic region and by rural and urban areas (as defined above), by age groups, by indigenous and non-indigenous populations and by SES tertiles.

Indigenous population was defined according to households in which at least one woman between 12 and 49 years of age spoke a Native language, defining children and women living in those households as indigenous. Likewise, children and women living in households who did not fit into this classification are referred to as non-indigenous.

SES conditions were assessed using information about construction materials used to build the house, sanitary infrastructure, services available and possession of selected household goods as reported by informants and by observing their conditions. Using this information the SES indicator was derived from the first component of a Principal Components Analysis. ${ }^{31}$ The resulting standardized factor scores were divided into tertiles or deciles, depending on the analysis. Further details on the derivation of the SES indicator can be found in a publication by Rivera et $a l^{9}$ in this issue.

The NNS-1999 used a design strategy and methods similar to the first National Survey conducted in 1988 in order to accurately describe changes in the population's nutritional status over the two survey periods. Both surveys measured anthropometry in children $<5$ years and women. Changes in the nutritional status of children and in the BMI distribution of women between surveys have been published elsewhere, ${ }^{8,32}$ and are discussed in this article.

Analyses were performed using Stata (Stata Statistical Software, Release 6.0, Stata Corporation College Station, TX) and SPSS (SPSS for Windows, Release 10.0.0. Chicago, IL, SPSS Inc., 1999) and considered the multistage sampling methodology.

\section{Results}

The main malnutrition problems were linear growth retardation (stunting), micronutrient deficiencies and anemia, and overweight and obesity.

\section{Stunting}

In Mexico, stunting continues to be an important public health problem in children $<5$ years of age while wasting is no longer a widespread problem at national or regional levels. At the national level almost one of every five children $<5$ years of age $(17.7 \%)$ were stunted while only $2 \%$ were wasted. The mean height-for-age z-score in this age group was $-0.8 \pm 1.3$ while the mean weightfor-height z-score was $+0.2 \pm 1.1$. Stunting occurs predominantly during the first two years of life. The prevalence increases almost 3 times between the first and the second year of life (form about $8 \%$ to $22 \%$ ) and remains at about $20 \%$ up to 4 years of age. From 5-11 years, the percent of children < -2 S.D. of the NCHS/ WHO distribution of height for age was $16.1 \%$. On average, adult women were short. The mean height of women 12-49 years of age was $152.9 \mathrm{~cm} .{ }^{8}$

So far national averages have been presented. However, stunting is distributed heterogeneously among population sub-groups. Figure 1 shows the prevalence of stunting for each region by urban and rural areas and in indigenous children. Prevalence in rural areas (31.6\%) is about 3 times higher than that found in urban areas $(11.6 \%)$ and the prevalence in the north (the wealthiest region) is much lower than in the south (the poorest region). The combination of regions and urban/rural areas results in the largest differences. For example, while the prevalence in urban areas of the north is about $6 \%$, the prevalence in the rural south is over $40 \%$, almost 7 times higher. $^{8}$

One of the groups with the poorest living conditions in Mexico is the indigenous population. Close to two thirds of the families of indigenous children $<5$ years of age are in the two lowest SES deciles, compared to less than $15 \%$ of the families of non-indigenous children. One of the articles in this issue ${ }^{9}$ compares the nutritional status of indigenous and non-indigenous children and investigates to what degree the SES indicator described above explains the differences. The prevalence of stunting is $\sim 3$ times higher in indigenous (44.3\%) compared to non-indigenous children (14.5\%) and the differences were reduced to about half when adjusting

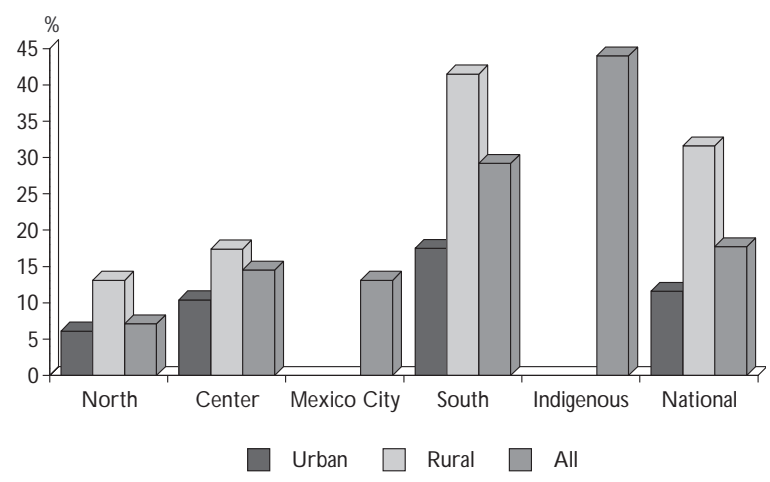

Figure 1. Prevalence of stunting in children $\measuredangle \mathbf{Y}$ BY REGION, URBAN AND RURAL AREAS AND FOR INDIGENOUSpopulation. National Nutrition Survey, Mexico, 1999 
for $\mathrm{SES}$, but remained significantly higher in indigenous children $(\mathrm{p}<0.05)$.

Figure 2 presents the prevalence of stunting by deciles of the SES indicator, with the first decile indicating the lowest socioeconomic conditions. There is a clear trend of increasing prevalence of stunting as the SES status deteriorates. The prevalence difference between the first $(47.6 \%)$ and the tenth $(4.6 \%)$ decile is $~ 10$ fold.

The prevalence of stunting, underweight and wasting in 1988 were $22.8 \%, 14.2 \%$, and $6 \%$, respectively and declined in 1999 to $17.7 \%, 7.6 \%$, and $2 \%$, respectively. Changes between surveys were 5.1 percent points for stunting (22.4\% relative to baseline), 6.6 percent points for underweight ( $46.5 \%$ relative to baseline) and 4 percent points for wasting (67\% relative to baseline).

\section{Micronutrient deficiencies and anemia}

\section{Children $<5$ years}

More than one in every four children $<5$ years of age $(27.2 \%)$ are anemic and between one-quarter to one half have one or more micronutrient deficiencies. The prevalence of iron, zinc and vitamin A deficiencies are at approximately $52 \%, 33 \%$ and $27 \%$, respectively. Also, over $25 \%$ of children have serum ascorbic acid concentrations indicative of low dietary intakes of vitamin C (Figure 4).

Some micronutrient deficiencies occur predominantly at younger ages. Anemia rates peak in the second year of life, when it affects almost half of all children, decreasing to about $17 \%$ prevalence at 4 years of age (Figure 3). Iron deficiency affects about two thirds of all children between 1 and 2 years and less than 50\% between 3 and 4 years of age (Figure 4 ).

In contrast to stunting, differences in anemia prevalences are not significantly different by region and

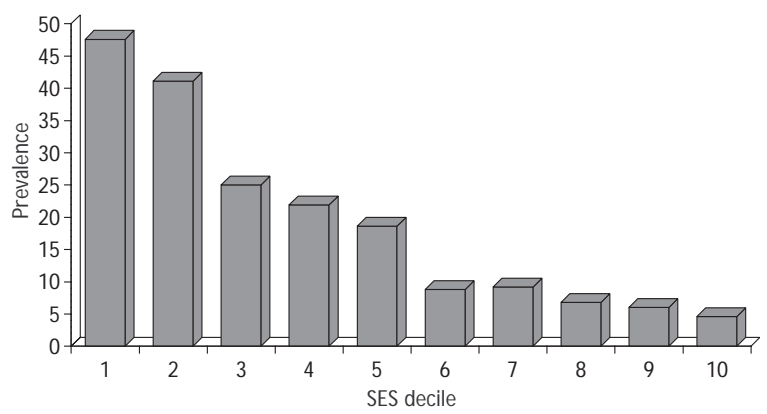

Figure 2. Prevalence of stunting by deciles of the Socio-economic Status indicator. National Nutrition SuRvey, Mexico, 1999 between urban and rural areas, but are higher in indigenous children (35.8\%) compared to non-indigenous children $(26.1 \%)$. These health inequities are much smaller than those found for stunting and are explained to a lesser degree by socioeconomic factors. ${ }^{9}, 13$

\section{Children 5-11 years of age}

The prevalence of anemia in children 5-11 years was $19.5 \%$ (Figure 3), slightly higher in rural $(21.9 \%)$ than urban $(18.3 \%)$ areas and in indigenous $(24.0 \%)$ than nonindigenous $(18.0 \%)$ children and much lower in Mexico City $(11 \%)$ than in other regions ( $18.0 \%$ to $24 \%)$.

The micronutrient with the highest deficiency prevalence was iron $(36 \%)$, followed by vitamin C (30\%), Vitamin A and Zinc (around 20\%) and folic acid (about 10\%) (Figure 4). Urban areas had much lower prevalence

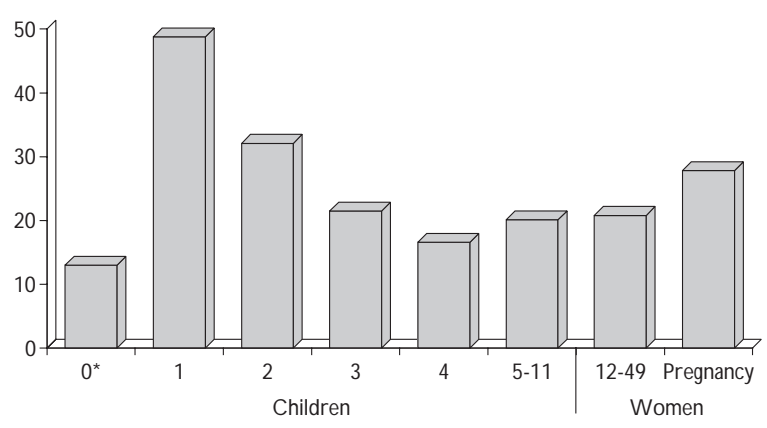

*6-11 mo

Figure 3. Prevalence of anemia in Children and Women. National Nutrition Survey, Mexico, 1999

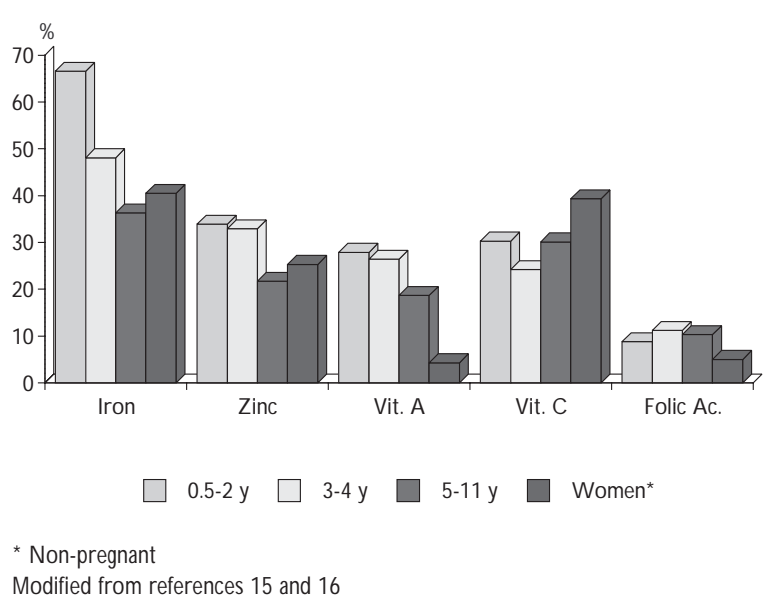

Figure 4. Prevalence of micronutrient deficiencies in Children and women. National Nutrition SurVey, MeXico, 1999 
of iron and zinc deficiencies ( $38.2 \%$ and $18.2 \%$, respectively) than rural areas ( $48.3 \%$ and $40 \%$, respectively). No differences were found in prevalence of vitamin deficiencies between rural and urban areas. ${ }^{15,16}$

\section{Women}

The national prevalence of anemia was $20 \%$ in non pregnant and $27.8 \%$ in pregnant women (Figure 3). In Mexico City, the prevalence of anemia was low $(16.4 \%$ non pregnant, $19.7 \%$ pregnant) and the highest prevalence was found in the south for non pregnant women $(23.2 \%)$ and in the north for pregnant women (31.2\%). Differences between rural and urban areas were small. The adjusted risk of anemia in non pregnant women was statistically significantly higher $(p<0.05)$ in the low and medium SES tertiles relative to the high tertile (Odds Ratios (OR) were 1.4 in the low and 1.3 in the medium SES tertiles relative to the high). The adjusted risk of anemia was higher in the south and north $(\mathrm{OR}=1.3)$ relative to Mexico City and in women with children relative to women without children $(\mathrm{OR}=1.5$ for $1-5$ children and 1.8 for $>5$ children)..$^{14}$

The micronutrients with the highest deficiency prevalence in non pregnant women were iron $(40.5 \%)$ and vitamin C (39.3\%), followed by zinc (25.3\%). Vitamin A and folic acid deficiencies were around 5\% (Figure 4). Urban areas had much lower levels of iron and zinc deficiency (36\% and $28 \%$, respectively) than rural areas (52\% and $34 \%$, respectively). No differences were found in vitamin deficiencies between rural and urban areas. 15,16

\section{Overweight and obesity}

Overweight and obesity have become a national epidemic in Mexico, particularly in adults, and it is already a concern in children.

\section{Children $<5$ years}

The national prevalence of overweight in children $<5$ years is $5.3 \%$ (Figure 5) with higher prevalence in the north $(7.2 \%)$ compared to the other regions ( $4 \%$ and $5 \%$ ) and in urban $(5.9 \%)$ than rural areas $(4.6 \%)$. The prevalence in 1988 was $4.2 \%$ (Figure 5); therefore the 11year increment was 1.1 percent points. ${ }^{8}$

\section{Children 5-11 years}

The combined prevalences of overweight and obesity in children $5-11$ years is $19.5 \%$ (Figure 5). The regions with the highest prevalences were Mexico City (26.6\%) and the north $(25.6 \%)$, followed by the center $(18.0 \%)$, and the south $(14.3 \%)$. The prevalence in urban areas $(22.9 \%)$ was much higher than in rural areas $(11.7 \%)$. However, when adjusted for other variables the differences by region and urban vs rural areas were no longer statistically significant. The adjusted prevalences were higher in females, children with more educated mothers (middle or high school) and higher socioeconomic status. ${ }^{10}$

\section{Women}

The combined prevalence of overweight and obesity in women 18-49 years of age (Figure 5) was 59.6\% at the national level (35.2\% overweight and $24.4 \%$ obesity), with the highest prevalence in the north $(65.3 \%)$, followed by Mexico City (59.1), the Center (58.6\%) and the south $(55.3 \%){ }^{32}$

The prevalences of overweight and obesity had a dramatic increase in the 11 years between surveys. The national prevalences of overweight and obesity in 1988 were $24.0 \%$ and $9.4 \%$, respectively (Figure 5 ). Therefore the increments were 10.3 percent points for overweight (a $41.3 \%$ increase relative to baseline) and 15 percent points for obesity (a 160\% increase relative to baseline).

\section{Dietary intake}

Median energy intake was $949 \mathrm{kcal}$ in children $<5$ years, $1377 \mathrm{kcal}$ in children 5-11 years (adequacies below 70\% for both age groups) and $1471 \mathrm{kcal}$ in non pregnant women. There is indication of under-reporting in children and clear evidence of under-reporting in women, particularly in those classified as obese. ${ }^{12}$ Evidence of protein adequacy was above $150 \%$ in children and almost $100 \%$ in women, despite under-reporting. Children $<12$ years in the North, Mexico City and urban areas

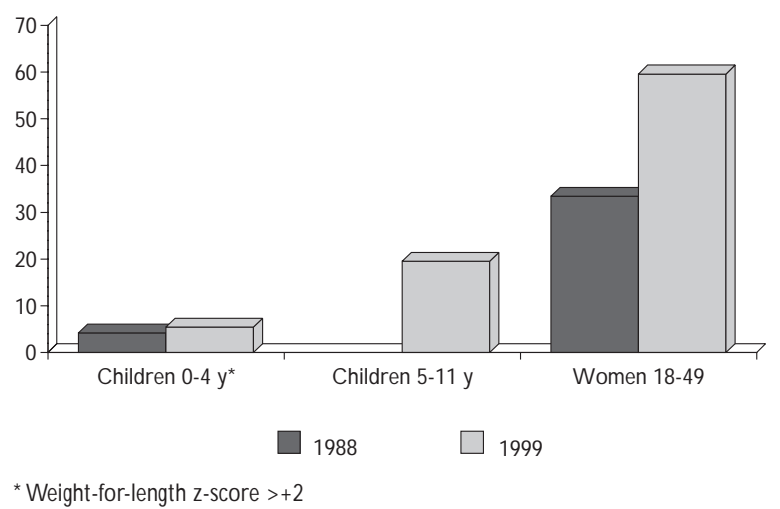

Figure 5. Prevalence of overweight and obesity COMBINED IN CHILDREN AND WOMEN IN 1988 AND 1999. National Nutrition Survey, Mexico, 1999 
had the highest fat and protein intake and the lowest fiber intake, while children in the south, rural areas, indigenous, and those in the lowest socio-economic group had the higher fiber intakes and the lowest fat intake. Children's carbohydrate intake was higher in the south for both age groups and was higher in urban areas.

The percent children at risk of dietary inadequacy ( $<50 \%$ adequacy) for micronutrient intakes were between $28 \%$ and $53 \%$ for children $<5$ years and between $23 \%$ and $77 \%$ for children 5-11 years. Children of both age groups in the south, in rural areas, in indigenous families and in the low SES tertile showed the higher risks of inadequacies for vitamin $\mathrm{A}$, vitamin $\mathrm{C}$, zinc and calcium, but not for iron and folate. ${ }^{11}$

The percentage of women at risk of dietary inadequacy was: $38.3 \%$ for vitamin A, $45.4 \%$ for vitamin C and $34.7 \%$ for folate. Carbohydrates, folate, iron and calcium intakes were significantly higher in rural than in urban areas. The risk of inadequate intake of vitamins $A$ and $C$ was higher in women of the lowest SES tertile. The highest SES tertile reported a significantly higher consumption of energy, protein, fat, cholesterol, vitamins A, C and zinc with the lower intake of fiber. ${ }^{12}$

\section{Breastfeeding}

The prevalence of exclusive breastfeeding (EBF) during the first 4 months of life was $25.7 \%$, and during the first 6 months of life $20.3 \%$. The rate of continued breastfeeding (second year) was $30.9 \%$, the median duration of BF was 9 months, and the national proportion of children ever breast-fed was $92.3 \%$. The probability of EBF for the first 4 months decreased with the infant's age, was higher in indigenous children and was not related to maternal education or employment. An interaction between infant sex and SEL was found: while the probability of EBF did not change much by SES in girls, it decreased sharply as SES increased in boys. ${ }^{17}$

\section{Discussion and Conclusions}

Malnutrition remains a serious public health problem in Mexico due to the magnitude of individuals affected in different stages of their lifecycle and the impact that this condition has on their health and performance. Stunting, several micronutrient deficiencies, overweight and obesity are now the main malnutrition problems in Mexico.

Stunting is present in almost one fifth of children < 5 years; the principal micronutrient deficiencies are iron deficiency which affects two thirds of children 1-2 years and one third to half of individuals at other ages, zinc deficiency in one fifth to one third individuals at different ages, vitamin A deficiency in 10\%-30\% children but not in women, vitamin C deficiency in $20 \%-40 \%$ of individuals at different ages, and folic acid deficiency in less than $10 \%$ at most ages. Overweight and obesity combined affect almost one fifth of all children 5-11 years and almost $60 \%$ of women (18-49 years).

The results come from a probabilistic national survey on almost 18,000 households, which produced reliable estimates of nutritional status for the entire population of Mexico, for urban and rural areas, and for the four regions. Micronutrient deficiencies were the only indicators for which sample sizes were not large enough to make regional comparisons.

The high proportion of women and children with dietary inadequacies related to Vitamin A, Vitamin C, folate, zinc, and iron intake are in general consistent with the deficiencies found in these same micronutrients using biochemical indicators. This affirms the direct link between inadequate dietary intake and the high prevalence of micronutrient deficiencies in México, despite the evidence of underreporting dietary intake.

The main exception to the consistency between dietary intake and deficiency, as assessed by biochemical indicators, is iron. The actual prevalence of iron deficiency in women and children is much higher than what would be expected from the risk as assessed by iron dietary intake. This apparent discrepancy between dietary intake and the blood concentration of the mineral can be explained in part by the bioavailability of different types of iron consumed in the population and by other dietary factors that inhibit the absorption of iron. A high proportion of the population in Mexico consume small amounts of meat, the source of heme iron which is most bioavailable, but consume large amounts of corn and beans which contain important quantities of phytic acid and other inhibitors of iron absorption. Consumption of milk, which also inhibits the absorption of iron when consumed in large quantities, is also relatively high ${ }^{33}$ For example, children $<5$ years consume on average $215 \mathrm{~g}$ of milk and milk products, $75 \mathrm{~g}$ of tortillas and only $20 \mathrm{~g}$ of meat per day; children $5-11$ years $180 \mathrm{~g}$ of milk, $160 \mathrm{~g}$ of tortillas, $45 \mathrm{~g}$ of beans and only $32 \mathrm{~g}$ of meat per day; and women $126 \mathrm{~g}$ of milk, $200 \mathrm{~g}$ of tortillas, $40 \mathrm{~g}$ of beans and only $40 \mathrm{~g}$ of meat per day. ${ }^{33}$ An analysis of the NNS-1999, published elsewhere, ${ }^{34}$ estimated iron bioavailability using dietary data in the sub-sample of children $<5$ years of age $(n=919)$. We found that the dietary intake of iron was relatively high $(6.2 \pm \mathrm{mg})$; however, only $0.3 \mathrm{mg}$ were heme iron and the intake of phytic acid was very high $(670 \mathrm{mg})$. The resulting bioavailable iron was only $0.25 \mathrm{mg}$ (3.9\% of all iron). This 
amount did not satisfy the mean physiologic requirements for this age group (0.54 and $0.87 \mathrm{mg}$ for $1-3$ and 4-6 year old children, respectively). ${ }^{35}$

Another discrepancy between the reported data on dietary intake and other evidence of nutritional status was that energy intake was universally low; while there is little wasting in children and a high prevalence of overweight and obesity in school age children and women. This is a reflection of the twenty-four hour recall method of dietary assessment, which tends to underestimate mean intakes. ${ }^{36}$ The degree of underestimation varies in different populations and may be associated with particular socio-cultural characteristics of the population. We have clear evidence of under-reporting in obese women $(\mathrm{BMI} \geq 30)$, who reported lower energy intake relative to estimated needs than non-obese women. Under-reporting in obese women was in the order of $80 \mathrm{Kcal}(\mathrm{p}<0.05)$ or $11.6 \%$ when expressed as a percent of energy requirements. ${ }^{12}$ Therefore, the discrepancy between the apparently low energy intake and the high prevalence of obesity are likely due to under-reporting. Under-reporting of intake may vary between micronutrients; this potential under-reporting may limit the validity of our data on micronutrient dietary intake. However, since the reported consumption of these nutrients was so low, even when under-reporting is taken into consideration it suggests that real deficiencies exist in a significant proportion of the population.

Most problems of undernutrition (stunting, anemia and some micronutrient deficiencies) are more prevalent in the poorest population: the south region, those living in rural areas and in indigenous families, and those belonging to the lower distribution of the SES indicator. Some of the differences in the prevalences by sub-populations were striking. For example, stunting was $\sim 3$ times more prevalent in rural than urban areas and in indigenous relative to non-indigenous children, the Rural south had a prevalence that was $\sim 7$ times higher than the urban north and the prevalence in the lower SES decile was 10 fold of that found in the upper decile. The prevalences of children and women with inadequate intakes of micronutrients were also higher among the poor.

Also, stunting, anemia and some micronutrient deficiencies, such as iron deficiency were more common during the first or second years of life. The strong association of undernutrition and micronutrient deficiencies with geographic, ethnic, socioeconomic factors and age indicate the need to target policies and programs for the prevention of undernutrition to the sub-populations with the highest prevalences. It is important to target the rural areas, the south, the indigenous population, and the lower socioeconomic groups. Also, policies or programs aimed at preventing stunting should target the gestation and the first two years of life, when stunting and micronutrient deficiencies occur. This is in agreement with findings from controlled supplementation trials that demonstrated higher effects of dietary improvements during gestation and the first two years of life. ${ }^{37,38}$

There is a clear need to develop policy and programs aimed at increasing the intake of iron, zinc, vitamin C, vitamin A, folic acid and calcium. Evidence from controlled trials indicates that supplementation with zinc ${ }^{39}$ and other micronutrients ${ }^{40,41}$ have positive effects on growth and reduces morbidity. The prevention of iron deficiency and anemia should start relatively early in life, by 4-6 months of life, when the iron reserves at birth may already be depleted. Other micronutrient status should be also improved early in life (since 6 months of age) to have larger effects on growth and nutritional status as shown by early supplementation with multiple micronutrients. ${ }^{40}$ Promotion of exclusive breastfeeding during the first six months of life must be an important component of any nutrition intervention in infants, given its positive effects on survival, nutritional status, cognitive development and prevention of infections and the possible reduction in risk of obesity later in life. ${ }^{17}$

The decline in wasting in children between 1988 and 1999 was quite dramatic and is most likely the result of universal health programs aimed at this population, such as ORT and vaccination and probably to better diets. The average observed reduction in stunting for South America between 1990 and $2000^{42}$ was 7.9 percent points (45.9\% relative to baseline). ${ }^{42}$ Far less impressive were the gains made in Mexico within the same time frame, with an absolute decline of 5.1 percent points ( $22.4 \%$ relative to baseline); this is despite the fact that Mexico has a tradition of high expenditure in food distribution programs..$^{43}$ These programs, enacted through 1988-1999, my not have reached their potential impact in part due to inadequate design and ineffective targeting of vulnerable populations. ${ }^{44}$

A number of large scale programs aimed at preventing and controlling undernutriton and micronutrient deficiencies are currently being implemented by the government and by non-government organizations. Some of the largest programs were designed or modified on the basis of the results of the NNS-1999 and incorporated evidence-based recommendations that improved their design and targeting substantially. One example is Oportunidades (formerly Progresa), a federal poverty alleviation program that combines a traditional cash transfer program with financial incentives for positive behaviors. Families do not receive the cash 
benefit unless they regularly attend health clinics, receive health education, and keep their children enrolled in and attending school. It begun in 1997 as a national program designed to address the immediate needs of extreme poverty and break its intergenerational transmission. The program covers currently approximately 4.2 million families (about $20 \%$ of all households) in both urban and rural areas that are selected on the basis of their low income. In addition to the cash transfers, the program provides micronutrient fortified foods to all children 4-23 months of age, to underweight children of 2-4 years and to pregnant and lactating women. A unique feature of the nutrition component of the program is its design by a group of experts in nutrition on the basis of existing evidence on the nutritional status of the population. ${ }^{45-47}$ Supplements were thus specifically designed for young children and women and contained the nutrients most deficient in their diet. ${ }^{48}$ The program was targeted to low income families, children $<2$ years and pregnant and lactating women and has a strong evaluation component as an essential part of the design. ${ }^{49}$ Evaluation of the nutritional impact of the program is in progress. Partial results indicate that children who were beneficiaries of the program were 25.5 percent less likely to be anemic and grew about 1 centimeter more after a year of program benefits than similar children who were not beneficiaries..$^{50}$

Other examples include a large scale multiplemicronutrient supplementation program which was directly motivated by the results of the NNS-1999 and thus aims to prevent anemia and micronutrient deficiencies in infants in predominantly indigenous communities. A subsidized milk distribution program, implemented during the last three decades, ${ }^{43}$ was recently modified on the basis of the NNS-1999 results. The program now gives weight to the importance of iron and zinc deficiencies by fortifying the milk with iron, zinc, vitamin $\mathrm{C}$ and other micronutrients deficient in the diets of children. The fortified milk is currently being distributed to about 4.6 million children 1-12 years of age. Evaluation of efficacy and effectiveness of the fortified milk program are currently underway.

Other programs-in-progress include the provision of vitamin A mega-doses to infants and young children of low income areas during immunization campaigns and the fortification of wheat flour and corn flour used to prepare tortillas. ${ }^{43}$

All the programs described above (except the fortification program) require education activities to ensure that the foods or supplements distributed reach the right individuals and are consumed in adequate amounts and frequency, in a sustainable manner. Nutrition education is also essential for improving the quality of the diet and care giving practices, even if supplements or food are distributed. One of the weaknesses of several programs that are currently underway in Mexico is the quality of their nutrition education component. State-of-the art approaches for the development of a communications strategy to effectively improve child-feeding and care giving practices, such as social marketing and formative research should be used. ${ }^{51-53}$

There is already good evidence that the combination of the different large scale, targeted programs described above will reduce the burden of undernutrition and micronutrient deficiencies in children and women. Evaluations currently in progress, as well as results of future probabilistic surveys, will inform adjustments or modifications of their design and implementation. In the meantime, however, much can be done to improve the potential impact of the programs by strengthening their nutritional education components.

In contrast to undernutrition, little is being done for the prevention and control of overweight and obesity. The dramatic increase between 1988 and 1999 of overweight and obese Mexicans signals an epidemiological emergency. The prevalence of overweight increased almost $50 \%$ and the prevalence of obesity increased more than three times over.

These dramatic changes in such a short period of time indicate that environmental factors are involved. Among the environmental factors that are likely responsible for this increase are greater intakes of energy-dense and low fiber diets in combination with reduced physical activity. It is likely that these environmental variables interact with genetic factors, resulting in a sharp increase in obesity.

There is solid evidence in the literature that obesity is a risk factor for various nutrition-related chronic diseases (NRCD), including type 2 diabetes, high blood pressure, cardiovascular disease (including stroke), some types of cancer, and other diseases ${ }^{3}$ which prematurely disable and kill a large proportion of economically productive individuals. Further, the cost of their treatment imposes an unacceptable burden on health systems.

For example, the impressive increase in the prevalence of overweight and obesity in Mexico is parallel to increases in age-adjusted death rates for various NRCD like diabetes mellitus, acute myocardial infarction and high blood pressure. ${ }^{32}$ If action is not taken soon, the epidemic of overweight and obesity may continue to grow and its impact on NRCD and the related demand for health services may be devastating.

Unfortunately there is little experience at the national level as well as internationally on effective interventions that prevent and control the growing epidemic 
of overweight and obesity. Study of the determinants of overweight and obesity and the design and evaluation of prevention strategies for controlling obesity in the population, based on existing evidence and international experience, is urgently needed and success stories should be brought to scale quickly to maximize impact. The possible interventions and actions that may prove to be effective include the promotion of physical activity at school and in the workplace, urban planning to encourage the use of public transportation, safe bicycling, expansion of parks and green areas for walking and exercising, less time watching television, and more active leisure. Also, the promotion of breastfeeding and adequate complementary feeding practices and the promotion of healthy diets, including higher intake of nonstarchy vegetables, fruits, legumes, nuts and whole grain products and lower intake of sugars, sodas, and saturated fats. The intake of healthy diets may be achieved through effective comunications strategies, food price and trade incentives, agricultural policies and control of mass media advertisement of less healthy foods.

The holistic purpose of health and nutrition surveys is their application in creating public awareness for both advocacy among policy makers and to inform interventions to improve public health and nutrition. The National Institute of Public Health has made significant efforts to achieve this. Over four years have passed since completion of the NNS-1999. This has been an intensive period of presentations given to decision makers, the private sector, the media, students and the scientific community in Mexico. It has also been a time to disseminate through publications such as this one in Salud Pública de México. While the results of the survey have been used for planning new nutrition interventions or improving the design of others that were already underway, the real measure of impact on the health of our society remains to be seen.

\section{References}

1. Martorell R. Results and implications of the IN CAP follow-up study. J Nutr 1995;125:1127S-1138S

2. Administrative Committee on Coordination. Sub-Committee on $\mathrm{N}$ utrition (ACC/SCN). Fourth Report on the World N utrition Situation. Geneva:ACC/SCN in collaboration with IFPRI, 2000.

3. Must A, Spadano J, Coakley EH, Field AE, Colditz G, Dietz W H. The disease burden associated with overweight and obesity. JAMA 1999; 282:1523-1529.

4.Thompson D, Edelsberg J, Colditz GA, Dird AP, Ester G. Lifetime health and economic consequences of obesity. Arch Intern Med 1999; 159:2177-2183 5. UNICEF. The State of the World's Children 1998. 0 xford: 0 xford University Press, 1998.
6.Popkin B.An overview on the nutrition transition and its health implications: The Bellagio meeting. Public Health N utr 2002; 5(1A): 93-103.

7. Resano-Pérez E, Méndez-Ramírez I, Shamah-Levy T, Rivera JA, Sepúlveda J. Methods of the $1999 \mathrm{~N}$ ational N utrition Survey: Results of a N ational Probabilistic Survey. Salud Publica Mex 2003;45 suppl 4:S558-S564.

8. Rivera-D ommarco J,Shamah-LevyT,Villalpando-H ernández S,G onzálezde Cossío T, Hernández-Prado B, Sepúlveda J. Encuesta $\mathrm{N}$ acional de N utrición 1999. Estado nutricio en niños y mujeres en México. Cuernavaca, Morelos, México: Instituto N acional de Salud Pública, 2001.

9. Rivera JA, Monterrubio EA, González-C ossío T, García-Feregrino R, García-Guerra A, Sepúlveda-Amor J. N utritional status of indigenous children younger than five years of age in Mexico: Results of a $\mathrm{N}$ ational Probabilistic Survey. Salud Publica Mex 2003;45 suppl 4: S466-S476.

10. Hernández B, Cuevas-N asu L, Shamah-Levy T, Monterubio-Flores E, Ramírez-Silva Cl, García-Feregrino R, Rivera JA, Sepúlveda-A mor J. Factors associated with overweight and obesity in Mexican school-age children: Results from the National Nutrition Survey (1999). Salud Publica Mex 2003;45 suppl 4: S551-S557.

11. Barquera S, Rivera JA, Safdie-Kanan M, Flores M, Campos-N onato I, Campirano F. Energy and nutrient intake in preschool and school age in Mexican children: $\mathrm{N}$ ational Nutrition Survey 1999. Salud Publica Mex 2003;45 suppl 4:S540-S550.

12. Barquera S, Rivera JA, Espinoza-Montero J, Safdie M, Campirano F, Monterrubio E. Energy and nutrient consumption in Mexican women 12 49 years of age: Analysis of the $N$ ational N utrition Survey, 1999. Salud Publica Mex 2003;45 suppl 4:S530-S539.

13.Villalpando S, Shamah-LevyT,Ramírez-Silva Cl,Mejía-Rodríguez F, Rivera JA. Prevalence of anemia in children 1 to 12 years of age. Results from a nation-wide probabilistic survey in Mexico. Salud Publica Mex 2003;45 suppl 4:S490-S498.

14. Shamah-Levy T,Villalpando S, Rivera JA, M ejía-Rodríguez F, CamachoCisneros M, Monterrubio-Flores E. Anemia in Mexican women: A public health problem. Salud Publica Mex 2003;45 suppl 4:S499-S507.

15. Villalpando S, Montalvo-Velarde I, Zambrano N, García-Guerra A, Ramírez-Silva $\mathrm{Cl}$, Shamah T, Rivera JA.Vitamins $\mathrm{A}$ and $\mathrm{C}$ and folate status in Mexican children under 12 years and women $12-49$ years:A probabilistic national survey. Salud Publica Mex 2003;45 suppl4:S508-S519.

16. Villalpando S, García-G uerra A, Ramírez-Silvia Cl, Mejía-Rodríguez F, Matute G, Shamah T, Rivera JA. Iron, zinc and iodine status in Mexican children under 12 years and women $12-49$ years of age. A probabilistic national survey. Salud Publica Mex 2003;45 suppl 4:S520-S529.

17. González-C ossío T, Moreno-Macías H, Rivera JA,Villalpando-Hernández S, Shamah-Levy T, Monterrubio-Flores E, Hernández-Garduño A. Breastfeeding practices in Mexico: Results from the Second $N$ ational $N$ utrition Survey, 1999. Salud Publica Mex 2003;45 suppl 4:S477-S489.

18.W orld Health 0 rganization. Measurement of nutritional impact. Geneva, W HO, 1979

19. Cole TJ, Bellizzi MC, Flegal KM, Dietz W H. Establishing a standard definition for child overweight and obesity worldwide: International survey. BMJ 2000; 320:1240-1243.

20.W orld $\mathrm{H}$ ealth $\mathrm{O}$ rganization (W HO ). 0 besity. Preventing and managing the global epidemic. Report of a W HO Consultation on 0 besity. Geneva:W HO, 1997.

21. World Health 0 rganization. The prevalence of anemia in women: $A$ tabulation of available information. $2^{\text {nd }}$ edition. G eneva: W HO 1992.

22. International N utritional Anemia Consultative Group. Guidelines for the control of maternal nutritional anemia. A report of the International N utritional Anemia Consultative Group (IN AG). W ashington, DC: IN ACG,1999.

23. Ruiz-A rgüelles $G$, Llorente-PetersA . Predicción algebraica de parámetros de serie roja de adultos sanos residentes en alturas de 0 a 2670 metros. Rev Invest Clin 1981;33:191-193. 
24. Hadary CJ, Haas JD. H emoglo bin correction factors for estimating the prevalence of iron deficiency anemia in pregnant women residing at high altitudes in Bolivia. Pan Am J Public Health 1999;6(6):392-399.

25. Instituto $\mathrm{N}$ acional de Estadística $\mathrm{G}$ eografía e Informática. Base de datos de la Encuesta y resultados complementarios. Estados U nidos Mexicanos. Conteo de población y vivienda 1995 [Producto en Disco Compacto]. A guascalientes, Ags, México: IN EGI,1997.

26. Herbert $\mathrm{V}$. The Herman Award Lecture. Nutrition science as a continually unfolding story: The folate and Vitamin B12 paradigm. Am J C lin N utr 1986; 46: 387-340.

27.W agner C. Folic acid. In: Present knowledge in nutrition. Brown M Ed. $5^{\text {th }}$ ed. W ashington, DC:The Nutrition Foundation, 1984:33.

28. Sauber lich HE.Ascorbic acid (vitamin C). In: Labbé RF Ed. Symposium on laboratory assessment of nutritional status. Clin Lab Med 1981;1:673-684. 29. Dietary reference intakes: Applications in dietary assessment. W ashington, DC : Institute of Medicine, $N$ ational A cademy Press, 2000:285. 30. National Research Council. Recommended dietary allowances. W ashington, DC: N ational A cademy Press, 1989.

31. Hair JF, Anderson RE, Tatham RL, Black W C. Multivariate data analysis with reading. $3^{\text {rd }}$ edition N ew York: Macmillan Publishin 1992.

32. Rivera JA, Barquera S, Campirano F, Campos I, Safdie M, Tovar V. Epidemiological and nutritional transition in Mexico: Rapid increase of non-communicable chronic diseases and obesity. Public Health $\mathrm{N}$ utr 2002; $5(1 \mathrm{~A}): 113-122$.

33. Ramírez-Silva Cl, Rivera-D ommarco J. Alimentos de mayor consumo en niños de 1 a 11 años de edad en México. X Congreso de Investigación en Salud Pública, Instituto N acional de Salud Pública, 2003 March 5-7; Cuernavaca, Morelos, México.

34. Rodríguez-Ramírez S. Ingestión de hierro biodisponible y factores asociados a hemoglobina en niños mexicanos entre 12 y 59 meses de edad (Tesis de Maestría en Ciencias de la Salud conA rea de C oncentración en N utrición). Cuernavaca Morelos, México: Escuela de Salud Pública de México, Instituto N acional de Salud Pública, 2002.

35. Institute of Medicine. D ietary reference intakes. Iron.W ashington, DC: $\mathrm{N}$ ational A cademy Press, 2001.

36. Gibson RS. Principles of nutritional assessment. 0 xford: 0 xford University Press, 1990.

37. Lechtig A, Habicht J-P, D elgado H, Klein RE, Yarbrough C, Martorell R. Effect of food supplementation during pregnancy on birthweight. Pediatrics 1975; 58: 627-635.

38. Schroeder DG, Martorell R, Rivera JA, Ruel MT, Habicht JP. Age differences in the impact of nutritional supplementation on growth.J $\mathrm{N}$ utr 1995;125:1051S-1059S.

39. Brown K, Peerson J M, Rivera J y Allen L. Effect of supplemental zinc on the growth and serum zinc concentration of prepubertal children: $\mathrm{A}$ meta-analysis of randomized controlled trials. A m J Clin N utr 2002;75:1062-1071.

40. Rivera JA, González-C ossío T, Flores M, Romero M, Rivera M,TéllezRojo MM et al. Multiple micronutrient supplementation increases the growth of Mexican Infants. Am J Clin N utr 2001;74:657-663.

41. Rivera J, Hotz C, G onzález-C ossío T, G arcía-G uerraA, N eufeld L. The effect of micronutrient deficiencies on child growth. J N utr (In press).

42.ACC/SCN .Administrative C omité on C oordination-Subcommittee on $N$ utrition. U nited N ations. Fourth Report on theW orld N utrition Situation: Geneva:ACC/SC N/IFPRI, 2000.

43. Barquera S, Rivera-D ommarco JA , G asca-G arcíaA. Políticas y programas de alimentación y nutrición en México. Salud Publica Mex 2001; 43:1-14. 44. Rivera-D o mmarco JA. Estrategias y acciones para corregir deficiencias nutricias. Bol Med Hosp Infantil Mex 2000:57:641-649.

45. Rivera J, González-Cossío T, Flores M, Hernández M, Lezana MA, Sepúlveda J. Déficit de talla y emaciación en menores de cinco años en distintas regiones y estratos en México. Salud Publica Mex 1995;37:95107.

46. Rivera J, Long K, González-Cossío T, Parra S, Rivera M, Rosado JL. Nutrición y Salud: un menú para la familia. En: Cuadernos de Salud. Problemas Pretansicionales. México, DF: Secretaría de Salud, 1994.

47. Rivera J, Bourges H, Arroyo P,C asanueva E, Chávez A, H alhali A et al. Deficiencia de Micronutrimentos. Diez problemas relevantes de salud pública en México. Cuernavaca, Morelos, México: Instituto Nacional de Salud Pública. 1999:7-57.

48. Rosado JL, Rivera J, López G, Solano L. D evelopment, production, and quality control of nutritional supplements for a national supplementation programme in Mexico. Food N utr Bull 2000;21:30-34.

49. Rivera J, Rodríguez G, ShamahT, Rosado JL, C asanueva E, Maulén I et al. Implementation, monitoring, and evaluation of the nutrition component of the Mexican Social Programme (PRO GRESA). Food Nutr Bull 2000; 21(1):35-42.

50. Gertler P, Rivera JA, Levy S, Sepúlveda J. Mexico's PRO G RESA: U sing a poverty alleviation program as an incentive for poor families to invest in child health. (submitted for publication).

51. Mora J0.W hat are the relative roles of processed complementary foods and behavioural change in improving nutritional status? The need for a market-oriented approach. Food N utr Bull 2000:21:83-86.

52. Rivera-D ommarco J, Santizo MC, Hurtado E. Diseño y evaluación de un programa educativo para mejorar las prácticas de alimentación en niños de 6 a 24 meses de edad en comunidades rurales de $G$ uatemala.W ashington, DC: O rganización Panamericana de la Salud, 1988.

53. D ickin K, G riffiths M, Piwoz E. D esigning by dialogue:A program planner's guide to consultative research for improving young child feeding.W ashington, DC,A cademy for Educational D evelopment, 1997. 